\title{
MAJOR MALFORMATIONS OF THE CENTRAL NERVOUS SYSTEM IN HUNGARY
}

\author{
A. CZEIZEL, M.D. \\ Research Fellow, National Institute of Public Health, Budapest \\ AND \\ C. RÉVÉSZ \\ Mathematician, National Institute of Public Health, Budapest
}

IN Hungary, congenital malformations have become one of the 10 most frequent causes of death, and in 1967 they caused 20 times more infant deaths than infectious diseases. The present study is an epidemiological survey of 1,315 cases and a family study of 534 cases of major malformations of the central nervous system in Hungary.

\section{MeTHODS}

Data on all major central nervous system malformations which occurred in children born in Budapest in the years 1963-67 were collected. They were divided into four categories-anencephaly, spina bifida cystica, encephalo-meningocele, and congenital hydrocephalus. During the period of the survey, $99.7 \%$ of Budapest deliveries took place in hospital; in Hungary the proportion was $97.8 \%$. Data were compiled from the following sources:

(1) all of the 31 maternity hospitals of Budapest, where the personal data and obstetric histories of malformed infants were abstracted from the obstetric registers;

(2) all of the 26 departments of pathological anatomy in Budapest, where data relating to infants who had died of CNS malformations were taken from the necropsy records;

(3) the register of Heim Pal Paediatric Hospital, which lists congenital malformations reported from the whole of Hungary including Budapest. This register was set up by directive of the Ministry of Health (40.827/1962);

(4) all of the eight surgical paediatric departments in Budapest, where data of infants treated surgically for CNS malformations were obtained.

The distribution of cases from the different sources is shown in Figure 1.

The collected data of 'index patients' were listed on 'personal cards' in order to avoid duplication of records. While planning the survey, several ways of forming an adequate control group were explored and eventually it was decided to use data of the general population of births reported in demographic yearbooks.

In addition to the Budapest births, for which fairly complete data were obtained, details of 963 country cases were also collected, mainly from the register of congenital malformations, but these were not included in the incidence studies and served only as additional material for examining the epidemiological characteristics of malformations and the type of inheritance.

A questionnaire with reply envelope and stamp attached was sent to the mothers of affected infants (352 in Budapest and 963 in the rest of the country). This served as a means of checking the personal and obstetric data compiled, and of investigating the epidemiological and familial characteristics of CNS malformations. The number of questionnaires completed and returned was $702(53.4 \%)$; 534 of them $(40.6 \%$ of the total) could be used. There were 281 questionnaires $(21.4 \%)$ which could not be

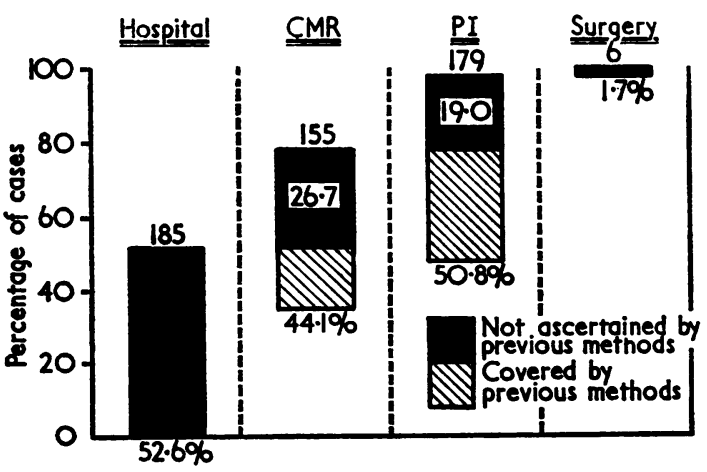

Fro. 1.-Ascertainment of cases from various sources in Budapest, 1963-67 (Hospital = maternity hospitals; CMR = Congenital Malformations Register; PI = pathological institutes; Surgery surgical paediatric departments). 
A. CZEIZEL AND C. RÉVÉSZ

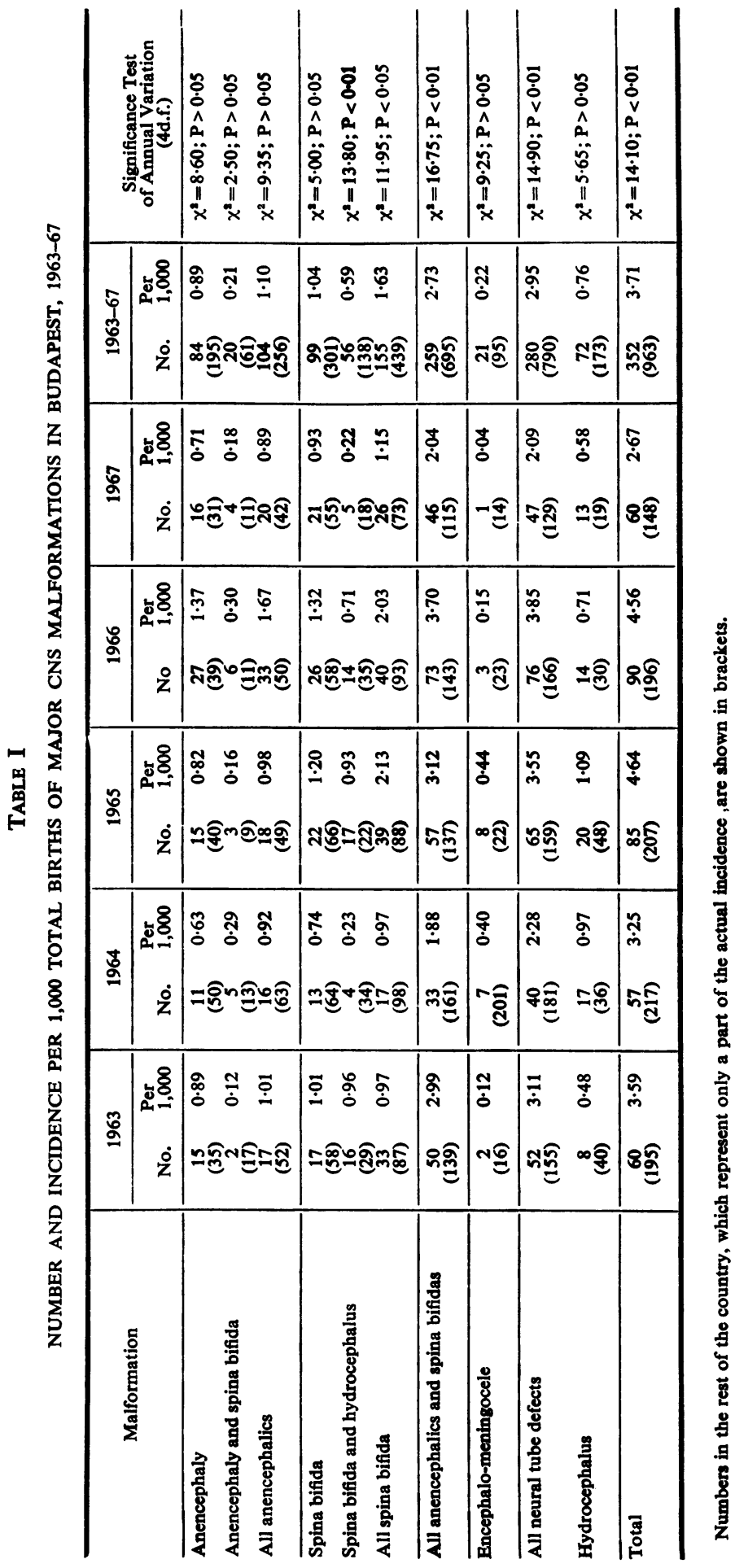

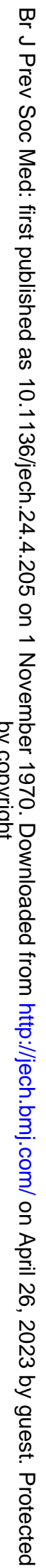


delivered because the address was wrong, and $\mathbf{3 3 2}$ questionnaires $(25.2 \%)$ were not returned.

The Budapest cases were analysed separately from those which occurred elsewhere; no considerable differences were noted. Analysis of the familial data was restricted to the 534 cases for whom satisfactorily completed questionnaires had been returned. The reported occurrence of CNS malformations in sibs was checked from hospital reports. Details of these cases are given in the Appendix. Five cases which could not be checked have been excluded. The analysis was carried out on a 'SZAM' computer.

\section{RESULTS}

\section{INCIDENCE IN BUDAPEST BIRTHS}

The annual incidence of CNS malformations in Budapest births is shown in Table I. (Numbers in the rest of the country are also presented in this table for convenience.)

In Budapest between 1963 and 1967 the incidence was 3.71 per 1,000 total births. The frequency of spina bifida associated with anencephaly was 100 times greater than that which would be expected if association were random, and association of spina bifida with congenital hydrocephalus was 280 times as frequent as expected. In view of this, cases of 'hydrocephalus with spina bifida' have generally been classed as spina bifida, and cases of 'anencephaly with spina bifida' have generally been included under the heading of anencephaly.

In Budapest spina bifida is the commonest neural tube defect (1.63 per 1,000 total births). Encephalomeningocele is often included in the spina bifida group, and this would raise the incidence to 1.85. The incidence of anencephaly was $1 \cdot 10$, and the total incidence of all neural tube defects was 2.95 per 1,000 total births.

Laurence, Carter, and David (1968a) considered that hydrocephalus is a heterogeneous category and that the reported frequency does not reflect the true incidence of the congenital condition, most cases being postnatal in origin, or macerated still births being wrongly regarded as hydrocephalics. In their series, spina bifida occurred about 10 times more frequently than congenital hydrocephalus. In our material the incidence of spina bifida was only twice as high as that of congenital hydrocephalus, and it therefore seems that our series of hydrocephalics is too heterogeneous for detailed aetiological study.

Statistical examination of the secular (annual) trend of neural tube defects and of congenital hydrocephalus in Budapest by the $\chi^{2}$ test suggested that the variation was more than random for spina bifida with hydrocephaly but not for the other groups when examined individually.
The incidence of CNS malformations in Budapest (3.71 per 1,000$)$ was rather higher than the average of a number of countries reported by Stevenson, Johnston, Stewart, and Golding (1966). This was mainly due to the relatively high incidence of spina bifida.

\section{Epidemological Characteristics}

The distribution of live births and still births and the sex ratio of the different types of malformations are shown in Table II.

The sex ratios (expressed as the proportion of males) are consistent with those reported from other countries. The female excess is particularly marked for anencephaly (67.5\% of whom were female). The sex ratios of anencephaly and spina bifida do not differ significantly from each other for either live births $\left(\chi_{1}^{2}=2.67 ; P>0.05\right)$ or still births $\left(\chi_{1}^{2}=0.20\right.$; $P>0.05)$.

There were 15 pairs of twins in the series. The type of twinning was not determined. Six were anencephalics, six had spina bifida, and three had congenital hydrocephalus. This frequency is in accordance with the rate expected based on the population frequency of twin births $(1.9 \%)$, although the values vary considerably for the different types of malformation (anencephaly $1.7 \%$; spina bifida $0.8 \%$; congenital hydrocephalus $1.2 \%$ ). These differences could well be due to the small numbers. In no instance were both members of the pair affected. A summary of these results and of other reports concerning anencephaly and spina bifida in twins is given in Table III. This shows a much less marked female preponderance among anencephalics in twin births than in single births. It also shows that concordant occurrence of anencephaly and spina bifida in twin sets is rare. This may not, however, be true of triplets (Scott and Paterson, 1966; Carter, David, and Laurence, 1968).

The distribution of birth weight of all births and of those with CNS malformations is shown in Table IV and Figure 2a. The percentage weighing less than 2,500g. was 81.7 for anencephaly, 20.6 for spina bifida, 29.0 for encephalo-meningocoele and 41.0 for hydrocephalus. An appreciable number of anencephalics weighed less than $1,000 \mathrm{~g}$. These findings are in agreement with those of Stevenson, Dudgeon and McClure (1959) and Nishimura, Takano, Tanimura, Yasuda and Uchida (1966), who found the frequency of neural tube defects much higher among miscarried foetuses than in the newborn. There is some relationship between birth weight and the frequency of still birth (Figure 2b); for neural tube defects of birth weight less than $3,000 \mathrm{~g}$. the proportion live born varies directly with birth weight. 
TABLE II

RATE OF LIVE BIRTHS AND STILL BIRTHS, AND SEX RATIO (PROPORTION OF MALES) OF MAJOR CNS MALFORMATIONS IN HUNGARY, 1963-67

\begin{tabular}{|c|c|c|c|c|c|c|c|c|}
\hline \multirow{3}{*}{ Malformation } & \multicolumn{8}{|c|}{ Live Births } \\
\hline & \multicolumn{2}{|c|}{ Number } & \multirow{2}{*}{$\underset{\text { Ratio }}{\text { Sex }}$} & \multirow{2}{*}{$\begin{array}{c}\text { Deviation of Sex } \\
\text { Ratio from } \\
\text { National Average }\end{array}$} & \multirow{2}{*}{$\underset{\text { Sex }}{\text { Unknown }}$} & \multicolumn{2}{|c|}{ Total $^{1}$} & \multirow{2}{*}{$\begin{array}{l}\text { Deviation of Live } \\
\text { Birth Rate from } \\
\text { National Average }\end{array}$} \\
\hline & $\mathbf{M}$ & $\mathbf{F}$ & & & & No & $\%$ & \\
\hline Anencephaly & 28 & 57 & $0 \cdot 329$ & $\begin{array}{l}\chi^{2}=13.25 \\
\mathbf{P}<0.001\end{array}$ & 5 & 90 & $\begin{array}{c}25 \cdot 0 \\
(26 \cdot 2)\end{array}$ & $\begin{array}{c}\chi^{2}=13,749.9 \\
P<0.001\end{array}$ \\
\hline Spina bifida & 211 & 287 & $0 \cdot 424$ & $\begin{array}{l}x^{2}=16.97 \\
P<0.001\end{array}$ & 7 & 505 & $\begin{array}{r}85 \cdot 0 \\
(91 \cdot 2)\end{array}$ & $\begin{array}{c}\chi^{2}=370.6 \\
P<0.001\end{array}$ \\
\hline Encephalo-meningocele & 49 & 50 & 0.495 & $\begin{aligned} \chi^{2} & =0.19 \\
P & >0.05\end{aligned}$ & $一$ & 99 & $\begin{array}{r}85 \cdot 3 \\
(90 \cdot 8)\end{array}$ & $\begin{array}{c}x^{2}=6,561 \cdot 0 \\
P<0.001\end{array}$ \\
\hline All neural tube defects & 288 & 394 & 0.422 & $\begin{array}{l}x^{2}=24.70 \\
P<0.001\end{array}$ & 12 & 694 & $\begin{array}{r}64.9 \\
(69.0)\end{array}$ & $\begin{array}{c}\chi^{2}=8,111 \cdot 3 \\
P<0.001\end{array}$ \\
\hline Hydrocephalus & 75 & 69 & 0.521 & $\begin{array}{l}x^{2}=0.01 \\
P>0.05\end{array}$ & 2 & 146 & $\begin{array}{r}59.6 \\
(66.4) \\
\end{array}$ & $\begin{array}{c}\chi^{2}=2,093.9 \\
P<0.001\end{array}$ \\
\hline Total (malformed births) & 363 & 463 & 0.439 & - & 14 & 840 & $\begin{array}{r}63.9 \\
(68.5)\end{array}$ & - \\
\hline Hungary (all births) & 353,834 & 331,026 & 0.517 & - & - & 684,860 & 98.9 & - \\
\hline
\end{tabular}

\begin{tabular}{|c|c|c|c|c|c|c|c|c|}
\hline \multirow{3}{*}{ Malformation } & \multicolumn{8}{|c|}{ Still Births } \\
\hline & \multicolumn{2}{|c|}{ Number } & \multirow{2}{*}{$\begin{array}{c}\text { Sex } \\
\text { Ratio }\end{array}$} & \multirow{2}{*}{$\begin{array}{c}\text { Deviation of Sex } \\
\text { Ratio from } \\
\text { National Average }\end{array}$} & \multirow{2}{*}{$\begin{array}{c}\text { Difference of Sex } \\
\text { Ratio in Live } \\
\text { Births and Still } \\
\text { Births }\end{array}$} & \multirow{2}{*}{$\begin{array}{c}\text { Unknown } \\
\text { Sex }\end{array}$} & \multicolumn{2}{|c|}{ Total $^{1}$} \\
\hline & $\mathrm{M}$ & $\mathrm{F}$ & & & & & No. & $\%$ อ \\
\hline Anencephaly & 58 & 122 & $0 \cdot 322$ & $\begin{array}{l}x^{2}=29.81 \\
P<0.001\end{array}$ & $\begin{array}{c}\chi_{1}^{2}=0.014 \\
P>0.05\end{array}$ & 74 & 254 & $\begin{array}{l}70 \cdot 6< \\
\left(73 \cdot 8 \frac{\pi}{6}\right.\end{array}$ \\
\hline Spina bifida & 14 & 25 & 0.359 & $\begin{array}{l}\chi^{2}=4.24 \\
P<0.05\end{array}$ & $\begin{array}{c}\gamma_{1}^{2}=0.622 \\
P>0.05\end{array}$ & 10 & 49 & $\begin{array}{c}8 \cdot 3 \overline{7} \\
(8 \cdot 8)\end{array}$ \\
\hline Encephalo-meningocele & 1 & 3 & 0.250 & $\begin{array}{c}\chi^{2}=1.21 \\
\mathbf{P}>0.05\end{array}$ & $\begin{array}{c}\chi_{1}^{2}=0.923 \\
P>0.05\end{array}$ & 6 & 10 & $\begin{array}{c}8 \cdot 6 \\
(9 \cdot 2)\end{array}$ \\
\hline All neural tube defects & 73 & 150 & 0.327 & $\begin{array}{c}\chi^{2}=35.64 \\
P<0.001\end{array}$ & $\begin{array}{c}x_{1}^{2}=6.316 \\
P<0.05\end{array}$ & 90 & 313 & $\begin{array}{c}29 \cdot 2 \\
(31 \cdot 0)\end{array}$ \\
\hline Hydrocephalus & 23 & 23 & $0 \cdot 500$ & $\begin{array}{l}\chi^{2}=0.10 \\
P>0.05\end{array}$ & $\begin{array}{c}\chi_{1}^{2}=0.061 \\
P>0.05\end{array}$ & 28 & 74 & $\begin{array}{r}30.2 \\
(33.6) \\
\end{array}$ \\
\hline Total (malformed births) & 96 & 173 & 0.357 & - & - & 118 & 387 & $\begin{array}{c}29 \cdot 4 \\
(31 \cdot 5)\end{array}$ \\
\hline Hungary (all births) & 4,092 & 3,718 & 0.524 & - & - & - & 7,810 & $\overline{1 \cdot 1}$ \\
\hline
\end{tabular}

\begin{tabular}{|c|c|c|c|c|c|c|c|c|c|c|c|}
\hline \multirow{3}{*}{ Malformation } & \multicolumn{5}{|c|}{ Unknown } & \multicolumn{6}{|c|}{ TOTAL } \\
\hline & Number & \multirow{2}{*}{$\begin{array}{c}\text { Sex } \\
\text { Ratio }\end{array}$} & \multirow{2}{*}{$\underset{\text { Sex }}{\text { Unknown }}$} & \multicolumn{2}{|c|}{ Total } & \multicolumn{2}{|c|}{ Number } & \multirow{2}{*}{$\underset{\text { Ratio }}{\text { Sex }}$} & \multirow{2}{*}{$\begin{array}{l}\text { Unknown } \\
\text { Sex }\end{array}$} & \multicolumn{2}{|c|}{ Total } \\
\hline & $\mathrm{M} F$ & & & No. & $\%$ & $\mathbf{M}$ & $\mathbf{F}$ & & & No. & $\%$ \\
\hline Anencephaly & 48 & $0 \cdot 333$ & 4 & 16 & $4 \cdot 4$ & 90 & 187 & 0.325 & 83 & 360 & 100 \\
\hline Spina bifida & $14 \quad 21$ & 0.400 & 5 & 40 & $6 \cdot 7$ & 239 & 333 & 0.418 & 22 & 594 & 100 \\
\hline Encephalo-meningocele & 33 & 0.500 & 1 & 7 & $6 \cdot 1$ & 53 & 56 & 0.486 & 7 & 116 & 100 \\
\hline All neural tube defects & $21 \quad 32$ & 0.396 & 10 & 63 & 5.9 & 382 & 576 & 0.399 & 112 & 1,070 & 100 \\
\hline Hydrocephalus & $12 \quad 11$ & 0.522 & 2 & 25 & $10 \cdot 2$ & 110 & 103 & 0.521 & 32 & 245 & 100 \\
\hline Total (malformed births) & $33 \quad 43$ & 0.434 & 12 & 88 & $6 \cdot 7$ & 492 & 679 & 0.420 & 144 & 1,315 & $\overline{100}$ \\
\hline Hungary (all births) & -- & - & - & - & - & 357,926 & 334,744 & 0.517 & - & 692,670 & 100 \\
\hline
\end{tabular}

1 Percentages live born and still born, after excluding births of unknown fate, are shown in parentheses. 
TABLE III

ANENCEPHALY AND SPINA BIFIDA IN TWINS

\begin{tabular}{|c|c|c|c|c|c|c|c|c|c|c|c|}
\hline \multirow[b]{2}{*}{ Neural Tube Defect } & \multirow[b]{2}{*}{ Author } & \multirow[b]{2}{*}{$\begin{array}{l}\text { Total } \\
\text { Cases }\end{array}$} & \multicolumn{5}{|c|}{ Discordant Pairs } & \multirow{2}{*}{$\begin{array}{l}\text { Con- } \\
\text { cordant } \\
\text { pairs }\end{array}$} & \multirow[b]{2}{*}{$\begin{array}{c}\text { Total } \\
\text { Sets }\end{array}$} & \multirow[b]{2}{*}{$\%$} & \multirow[b]{2}{*}{$\begin{array}{c}\text { Sex } \\
\text { Ratio } \\
\end{array}$} \\
\hline & & & $\mathbf{M M}$ & $\underset{\text { FF }}{\text { Sex }}$ & $\begin{array}{l}\text { of } \mathbf{T w} \\
\mathbf{M F}\end{array}$ & $\begin{array}{l}\text { Sets } \\
\text { FM }\end{array}$ & $?$ & & & & \\
\hline Anencephaly & $\begin{array}{l}\text { Gruber (1934) } \\
\text { Bök and Rayner (1950) } \\
\text { Record and McKeown (1951) } \\
\text { Wilson (1955) } \\
\text { Coffey and Jessop (1957) } \\
\text { Dumoulin and Gordon (1959) } \\
\text { Fŕzzal et al (1964) } \\
\text { Williamson (1965) } \\
\text { Stevenson et al. (1966) } \\
\text { Yen and MacMahon (1968) } \\
\text { Carter et al. (1968) } \\
\text { Butler and Alberman (1969) } \\
\text { Present Study }\end{array}$ & $\begin{array}{l}? \\
67 \\
? \\
? \\
137 \\
? \\
402 \\
29 \\
436 \\
782 \\
364 \\
494 \\
360\end{array}$ & $\begin{array}{l}0 \\
2 \\
4 \\
1 \\
1 \\
2 \\
3 \\
0 \\
6 \\
4 \\
2 \\
4 \\
0\end{array}$ & $\begin{array}{r}\mathbf{0} \\
1 \\
13 \\
0 \\
0 \\
0 \\
\mathbf{2} \\
\mathbf{2} \\
3 \\
5 \\
\mathbf{3} \\
\mathbf{3} \\
\mathbf{1}\end{array}$ & $\begin{array}{l}0 \\
0 \\
3 \\
0 \\
1 \\
1 \\
1 \\
0 \\
0 \\
3 \\
0 \\
1 \\
4\end{array}$ & $\begin{array}{l}1 \\
0 \\
4 \\
0 \\
0 \\
0 \\
0 \\
0 \\
2 \\
1 \\
1 \\
2 \\
1\end{array}$ & $\begin{array}{l}1 \\
\mathbf{0} \\
\mathbf{0} \\
1 \\
0 \\
0 \\
1 \\
\mathbf{0} \\
\mathbf{0} \\
\mathbf{1} \\
\mathbf{0} \\
\mathbf{2} \\
\mathbf{0}\end{array}$ & $\begin{array}{l}\text { 1(FF) } \\
0 \\
0 \\
0 \\
0 \\
0 \\
0 \\
0 \\
0 \\
0 \\
0 \\
0 \\
0\end{array}$ & $\begin{array}{r}3 \\
3 \\
24 \\
2 \\
2 \\
3 \\
7 \\
2 \\
11 \\
14 \\
6 \\
12 \\
6\end{array}$ & $\begin{array}{r}4.5 \\
\bar{y} \\
1.5 \\
1 . \overline{7} \\
6.9 \\
2.5 \\
1.8 \\
1.6 \\
2.4 \\
1.7\end{array}$ & $\begin{array}{l}0.000 \\
0.666 \\
0.292 \\
1.000 \\
1.000 \\
1.000 \\
0.666 \\
0.000 \\
0.545 \\
0.538 \\
0.333 \\
0.500 \\
0.666\end{array}$ \\
\hline Total & & 3,071 & 29 & 33 & 14 & 12 & 6 & 1 & 95 & 205 & 0477 \\
\hline Spina bifida & $\begin{array}{l}\text { Record and McKeown (1951) } \\
\text { Dumoulin and Gordon (1959) } \\
\text { Stevenson et al.(1966) } \\
\text { Yen and MacMahon (1968) } \\
\text { Carter et al. (1968) } \\
\text { Butler and Alberman (1969) } \\
\text { Present Study }\end{array}$ & $\begin{array}{l}\stackrel{?}{?} \\
355 \\
1,009 \\
425 \\
250 \\
710\end{array}$ & $\begin{array}{r}10 \\
0 \\
4 \\
4 \\
2 \\
1 \\
2\end{array}$ & $\begin{array}{r}8 \\
0 \\
1 \\
10 \\
2 \\
3 \\
3 \\
2\end{array}$ & $\begin{array}{l}1 \\
1 \\
1 \\
1 \\
1 \\
1 \\
2 \\
1\end{array}$ & $\begin{array}{l}6 \\
0 \\
2 \\
0 \\
2 \\
1 \\
1\end{array}$ & $\begin{array}{l}\mathbf{0} \\
\mathbf{0} \\
\mathbf{0} \\
\mathbf{1} \\
\mathbf{0} \\
\mathbf{0} \\
\mathbf{0}\end{array}$ & $\begin{array}{l}0 \\
0 \\
1(\text { FF }) \\
0 \\
0 \\
0 \\
0\end{array}$ & $\begin{array}{r}25 \\
1 \\
9 \\
16 \\
7 \\
7 \\
6\end{array}$ & $\begin{array}{l}\overline{-} \\
2.5 \\
1.6 \\
1.6 \\
2.8 \\
0.8\end{array}$ & $\begin{array}{l}0.440 \\
1.000 \\
0.500 \\
0.333 \\
0.428 \\
0.428 \\
0.500\end{array}$ \\
\hline Total & & 2,749 & 23 & 26 & 8 & 12 & 1 & 1 & 71 & 1.64 & 0.437 \\
\hline Total & & & 52 & 59 & 22 & 24 & 7 & 2 & 166 & & 0.465 \\
\hline
\end{tabular}

Reports restricted to one twin set were omitted. We could not learn the sex of twins in the cases of Smithells et al. (1964) and Gittelsohn and Milham (1965), but the latter series included 86 affected sets, in 10 of which both members were affected.

In anencephaly sex ratio also varies considerably according to weight, the proportion of males being lower in the low weight classes. In congenital hydrocephalus the trend is in the opposite direction (Figure 2c).

The monthly variation of malformed and total births is shown in Table V. In anencephaly, encephalo-meningocele and congenital hydrocephalus, there was no considerable variation but a conspicuous seasonal variation was noted in spina bifida cases. In the late winter and early spring months (February, March and April) the incidence was high, with a peak in March when it was $50 \%$ above the annual rate. In July it was $45 \%$ below average. This pattern was observed in each of the five years of the investigation (see Figure 3). It is possible that some aetiological agent may exert most influence in Hungary in July, August and September upon embryos conceived in May, June and July. A conspicuous increase of incidence could be noticed also in October 1964 and in November 1966. There were no consistent monthly variations in the proportion live born or in the sex ratio.

In Birmingham and Scotland (McKeown and Record, 1951), Germany (Tünte, 1968) and Italy (Beolchini and Bailo, 1965) an increased incidence of anencephaly in the winter months has been demonstrated. On the other hand, in France
(Frézal, Kelley, Guillemot and Lamy, 1964), the United States (MacMahon, Pugh, and Ingalls, 1953) and Liverpool (Smithells, Chinn and Franklin, 1964) no such seasonality of anencephaly has been observed; later investigations (Leck and Record, 1966) have shown that the seasonal variation previously reported in Birmingham and Scotland, is no longer present. Little seasonal variation in spina bifida was noted in any of these reports but Guthkelch (1962) found an increased incidence in early spring (March) in Manchester and also demonstrated a similar trend in Scotland. Slater, Watson, and McDonald (1964) reported similar results in England and Wales.

The relation of CNS malformations to maternal age is examined in Table VI. In anencephaly, spina bifida, encephalo-meningocele and congenital hydrocephalus no significant departures from population values were observed. In neural tube defects the rather slight difference of the single components add up to a significant difference when these malformations are combined, but no consistent trend is evident. Deviation is most marked in mothers of anencephalics in the age-group 20-24 years, and in encephalo-meningocoele cases in mothers over 35 . No significant difference could be established for congenital hydrocephalics because of the small number of cases, though their frequency is higher over 35 


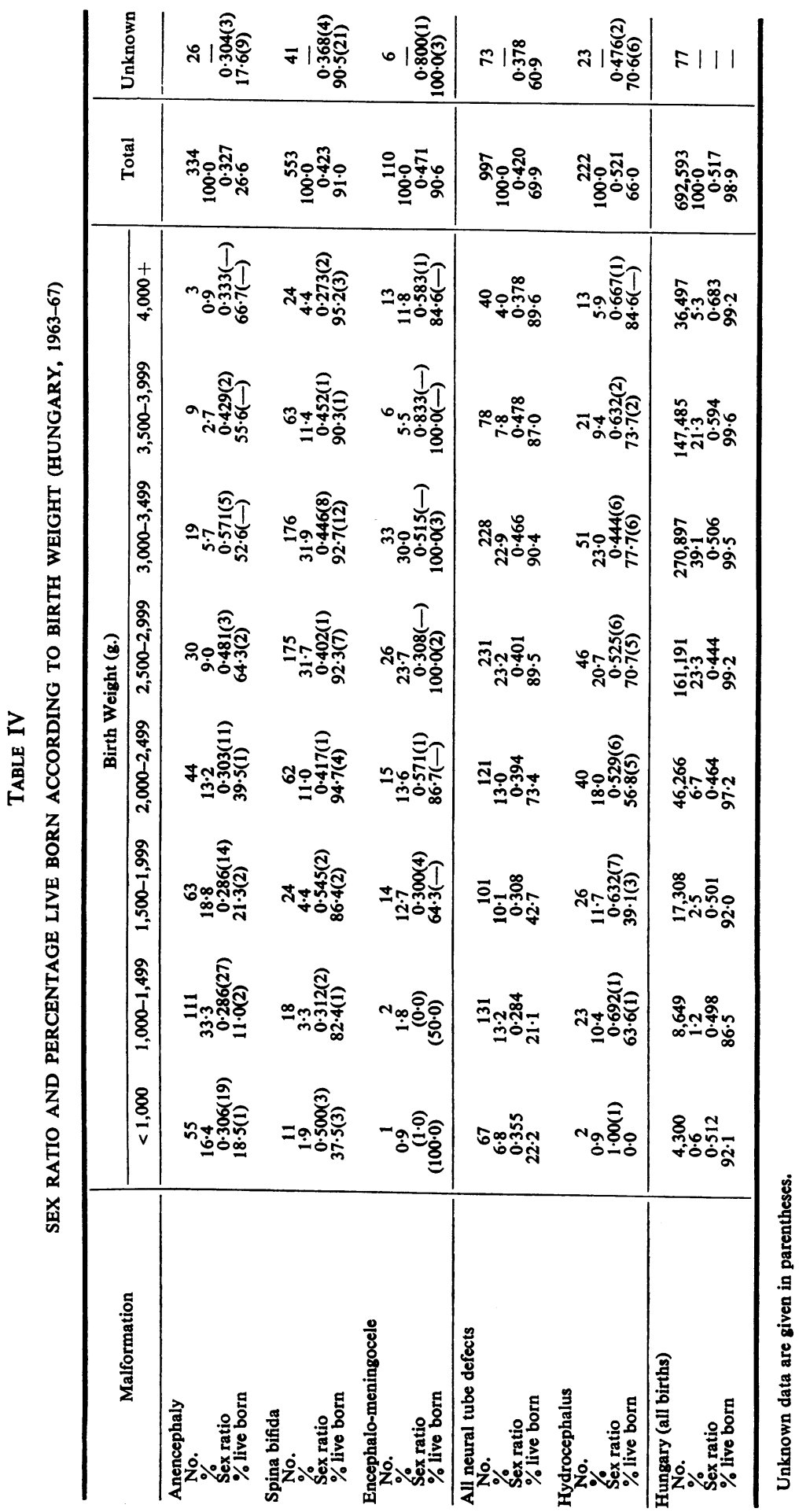




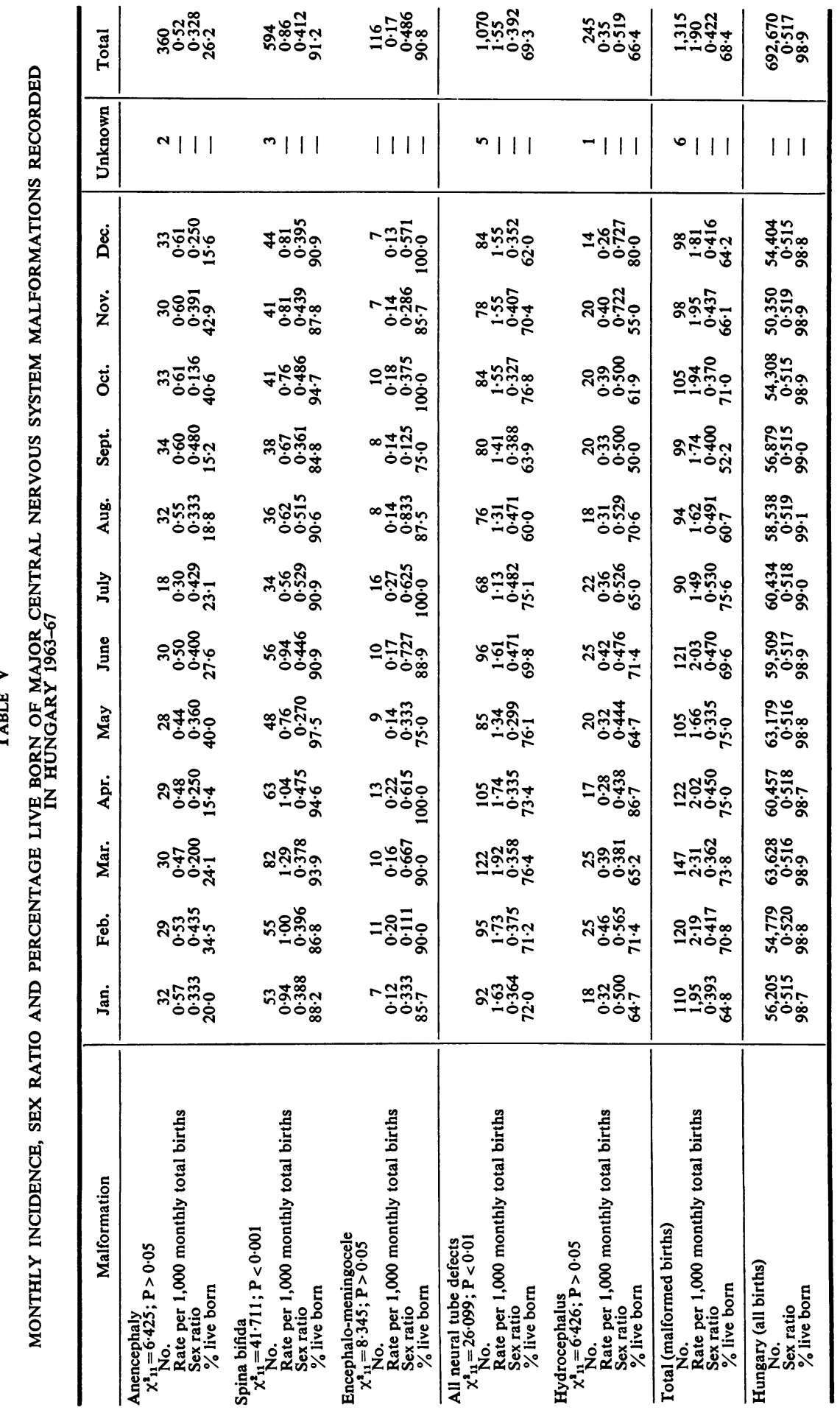



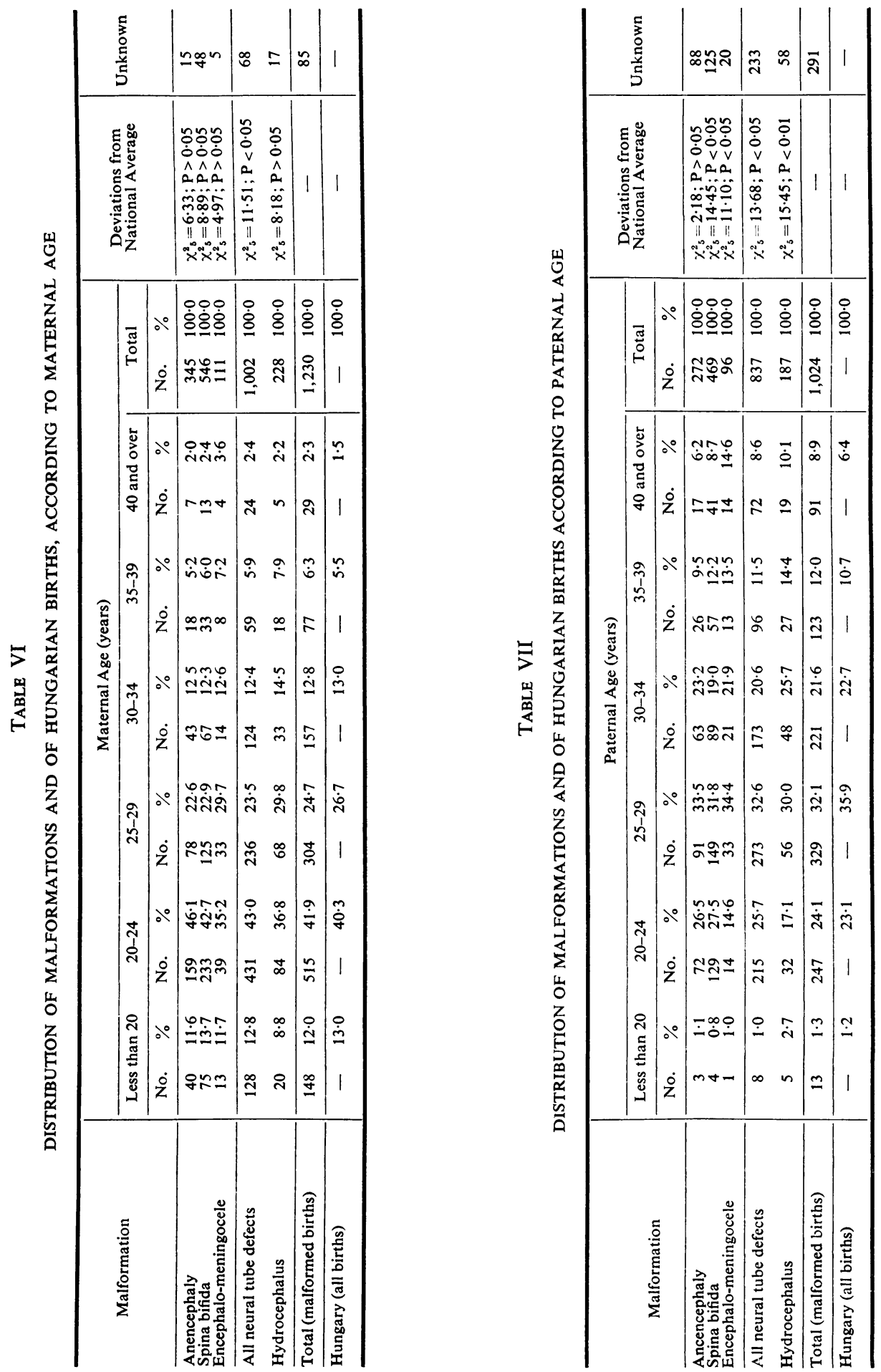

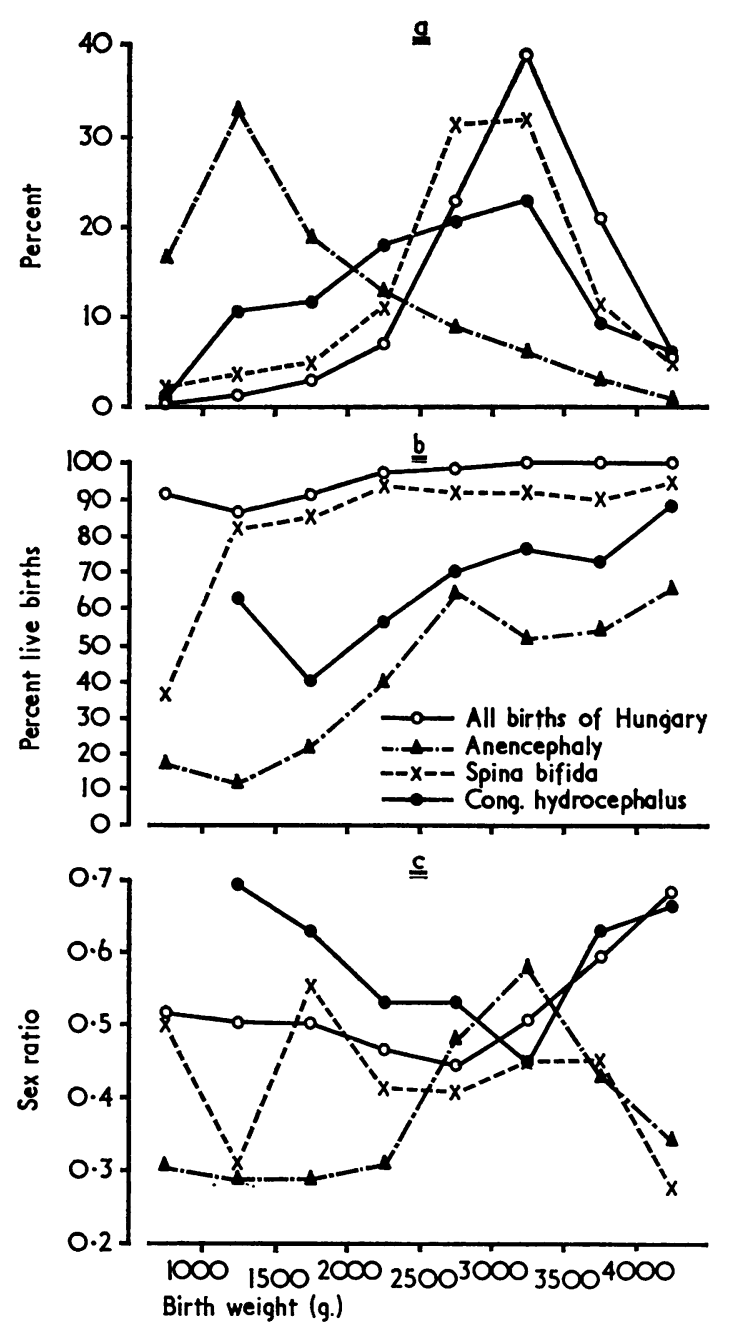

Fig. 2.- (a) Percentage distribution of birth weight of all Hungarian births and of those with anencephaly, spina bifida and congenital hydrocephalus; (b) percentage live born according to birth weight; (c) sex ratio according to birth weight.

years $(10 \cdot 1 \%$ compared to $7 \%$ in the controls). Investigations carried out in England and the United States have shown that the incidence of congenital hydrocephalus increases with the age of the mother, but in neural tube defects this relationship is less marked (Penrose, 1946; Record and McKeown, 1949; Ingalls, Pugh and MacMahon, 1954; Edwards, 1958).

Distribution by paternal age differs significantly from the national average for all the malformation groups except anencephaly (Table VII). The proportion of hydrocephalics with fathers aged 35 years or over was $24.5 \%$ and the proportion for cases of encephalo-meningocele was $28.1 \%$. The national figure for all births was only $17 \cdot 1 \%$.

The distribution of cases according to birth order is shown in Table VIII. It confirms the findings of other authors concerning the higher frequency of anencephaly and spina bifida cases in the first-born (Record and McKeown, 1949; MacMahon et al., 1953; Ingalls et al., 1954; Edwards, 1958). Investigations carried out in England and the United States have shown that the occurrence of neural tube defects increases after the fifth confinement, and Record (1961) has found this phenomenon to be independent of socio-economic status. In the case of congenital hydrocephalus the effect of parity is not apparent (Ingalls et al., 1954).

When the birth order distribution of neural tube defects (anencephaly, spina bifida and encephalomeningocele) within each maternal age group is examined, it is seen that the higher frequency observed among first-born increases with the age of the mother (Table IX). A higher frequency is also found in the sixth to ninth pregnancies of mothers over 40 . Examination of maternal age distribution in the first four pregnancies also shows that for third- and fourth-born, neural tube defects are more frequent among the children of older mothers (Figure 4).

Examination according to parents' occupation (divided broadly into physical and agricultural workers and non-manual workers) showed no obvious association with incidence.

\section{FAMIIIAL INCIDENCE}

The incidence of neural tube defects in the family of index patients is shown in Table X.

The proportion of brothers and sisters who were also affected with anencephaly or spina bifida was $3.1 \%$. This rate is 10.3 times higher than the population incidence. If unidentified cases are included, the incidence in sibs becomes $4 \%$. It is interesting to note that in the spina bifida group all nine of the affected sibs were females and that four of them were children of the same mother.

Among second-degree relatives (uncles and aunts) the incidence of neural tube defects was below the population value and the incidence in third-degree relatives (cousins) exceeded it only slightly. The higher incidence noted in the maternal side of the family is worth mentioning (see Williamson, 1965). A possible explanation is that women know more about their own than about their husbands' families.

For encephalo-meningocele the familial incidence is extremely low (only one case among 1,288 family members). There seemed to be no familial concentration in the case of congenital hydrocephalus. 


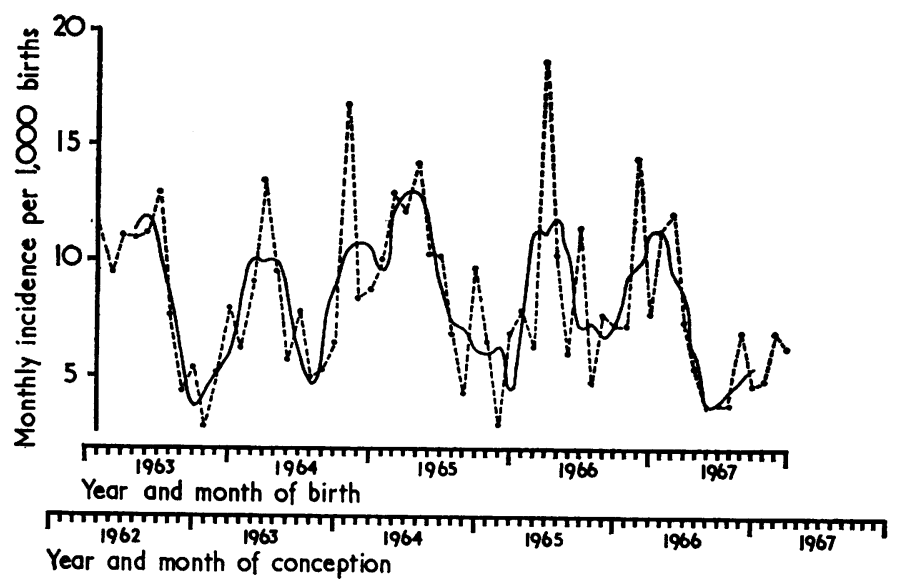

Fig. 3.-Monthly incidence per 1,000 births of spina bifida in Hungary, 1963-67. (The unbroken line shows the moving average.)

In the family of index patients with anencephaly or spina bifida a mixed incidence of these malformations was found but in second- and third-degree relatives of index patients affected with neural tube defects it was (with one exception) always spina bifida cases that were registered. The incidence of neural tube defects in relatives of index patients with congenital hydrocephalus and, conversely, of congenital hydrocephalus in relatives of index patients with neural tube defects was not higher than the population incidence.

It is difficult to estimate accurately the incidence of neural tube defects in relatives. In this series $59 \%$ of the mothers of anencephalics were not aware of any abnormality in their infants. The remainder had been told that their infants had been deformed, but they did not know the exact type of the malformation. Consequently a reliable history of neural tube defects in second- and third-degree relatives could hardly be expected and reported incidences are likely to be under-estimates. Spina bifida is perhaps better reported than anencephaly because some survive and this may explain why its apparent incidence among relatives in this study is higher than that of anencephaly.

Familial concentration of neural tube defects has

TABLE VIII

DISTRIBUTION OF MALFORMATIONS AND OF HUNGARIAN BIRTHS, ACCORDING TO BIRTH ORDER

\begin{tabular}{|c|c|c|c|c|c|c|c|c|c|}
\hline & \multicolumn{7}{|c|}{ Birth Order } & \multirow{2}{*}{$\begin{array}{l}\text { Deviations from } \\
\text { National Average }\end{array}$} & \multirow[b]{2}{*}{ Unknown } \\
\hline & 1 & 2 & 3 & 4 & $5-6$ & $7+$ & Total & & \\
\hline $\begin{array}{l}\text { Anencephaly } \\
\text { No. } \\
\%\end{array}$ & $\begin{array}{r}222 \\
66 \cdot 7\end{array}$ & $\begin{array}{r}65 \\
19 \cdot 5\end{array}$ & $\begin{array}{r}20 \\
6.0\end{array}$ & $\begin{array}{r}7 \\
2 \cdot 1\end{array}$ & $\begin{array}{r}12 \\
3 \cdot 6\end{array}$ & $\begin{array}{r}7 \\
2 \cdot 1\end{array}$ & $\begin{array}{r}333 \\
100 \cdot 0\end{array}$ & $x^{2}{ }_{s}=48.56 ; P<0.001$ & 27 \\
\hline $\begin{array}{l}\text { Spina bifida } \\
\text { No. } \\
\%\end{array}$ & $\begin{array}{r}322 \\
60 \cdot 0\end{array}$ & $\begin{array}{r}126 \\
23.5\end{array}$ & $\begin{array}{r}46 \\
8 \cdot 6\end{array}$ & $\begin{array}{r}17 \\
3 \cdot 2\end{array}$ & $\begin{array}{r}16 \\
3 \cdot 0\end{array}$ & $\begin{array}{r}10 \\
1 \cdot 7\end{array}$ & $\begin{array}{r}537 \\
100 \cdot 0\end{array}$ & $\chi^{2}{ }_{s}=31.77 ; P<0.001$ & 57 \\
\hline $\begin{array}{l}\text { Encephalo-meningocele } \\
\text { No. } \\
\%\end{array}$ & $\begin{array}{l}60 \\
54 \cdot 5\end{array}$ & $\begin{array}{l}27 \\
24 \cdot 5\end{array}$ & $\begin{array}{l}8 \\
7 \cdot 3\end{array}$ & $\begin{array}{c}3 \\
2 \cdot 8\end{array}$ & $\begin{array}{c}5 \\
4 \cdot 5\end{array}$ & $\begin{array}{c}7 \\
6 \cdot 4\end{array}$ & $\begin{array}{r}110 \\
1000\end{array}$ & $\chi^{2}{ }_{s}=10.11 ; P>0.05$ & 6 \\
\hline $\begin{array}{l}\text { All neural tube defects } \\
\text { No. } \\
\%\end{array}$ & $\begin{array}{r}604 \\
61 \cdot 6\end{array}$ & $\begin{array}{r}218 \\
22 \cdot 3\end{array}$ & $\begin{array}{r}74 \\
7 \cdot 6\end{array}$ & $\begin{array}{r}27 \\
2 \cdot 8\end{array}$ & $\begin{array}{r}33 \\
3 \cdot 3\end{array}$ & $\begin{array}{r}24 \\
2 \cdot 4\end{array}$ & $\begin{array}{r}980 \\
100 \cdot 0\end{array}$ & $\chi^{2}=76 \cdot 14 ; P<0.001$ & $\underline{90}$ \\
\hline $\begin{array}{l}\text { Hydrocephalus } \\
\text { No. } \\
\%\end{array}$ & $\begin{array}{r}125 \\
56 \cdot 0\end{array}$ & $\begin{array}{r}47 \\
21 \cdot 1\end{array}$ & $\begin{array}{r}23 \\
10 \cdot 3\end{array}$ & $\begin{array}{r}13 \\
5 \cdot 9\end{array}$ & $\begin{array}{r}9 \\
4 \cdot 0\end{array}$ & 2.7 & $\begin{array}{r}223 \\
100 \cdot 0\end{array}$ & $\chi^{2}{ }_{5}=10.71 ; P>0.05$ & 22 \\
\hline $\begin{array}{l}\text { Total (Malformed Births) } \\
\text { No. } \\
\% \\
\end{array}$ & $\begin{array}{r}729 \\
60 \cdot 6 \\
\end{array}$ & $\begin{array}{r}265 \\
22 \cdot 0 \\
\end{array}$ & $\begin{array}{r}97 \\
8 \cdot 1\end{array}$ & $\begin{array}{r}40 \\
3 \cdot 3 \\
\end{array}$ & $\begin{array}{r}42 \\
3 \cdot 5 \\
\end{array}$ & $\begin{array}{r}30 \\
2 \cdot 5\end{array}$ & $\begin{array}{l}1,203 \\
100 \cdot 0\end{array}$ & - & 112 \\
\hline $\begin{array}{l}\text { Hungary (All Births) } \\
\%\end{array}$ & $47 \cdot 9$ & $30 \cdot 7$ & $10 \cdot 2$ & $4 \cdot 5$ & $4 \cdot 1$ & $2 \cdot 6$ & $100 \cdot 0$ & - & - \\
\hline
\end{tabular}




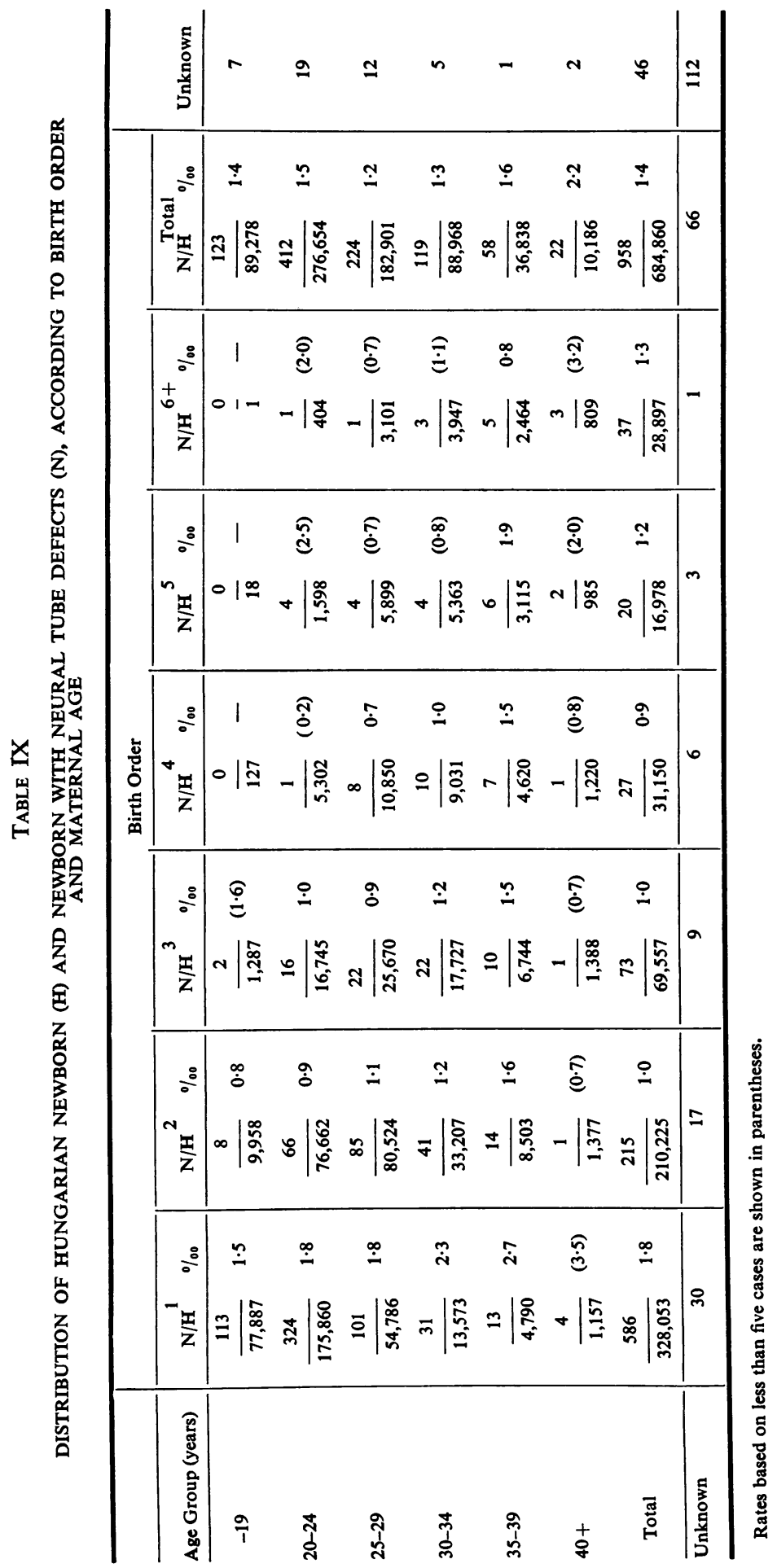




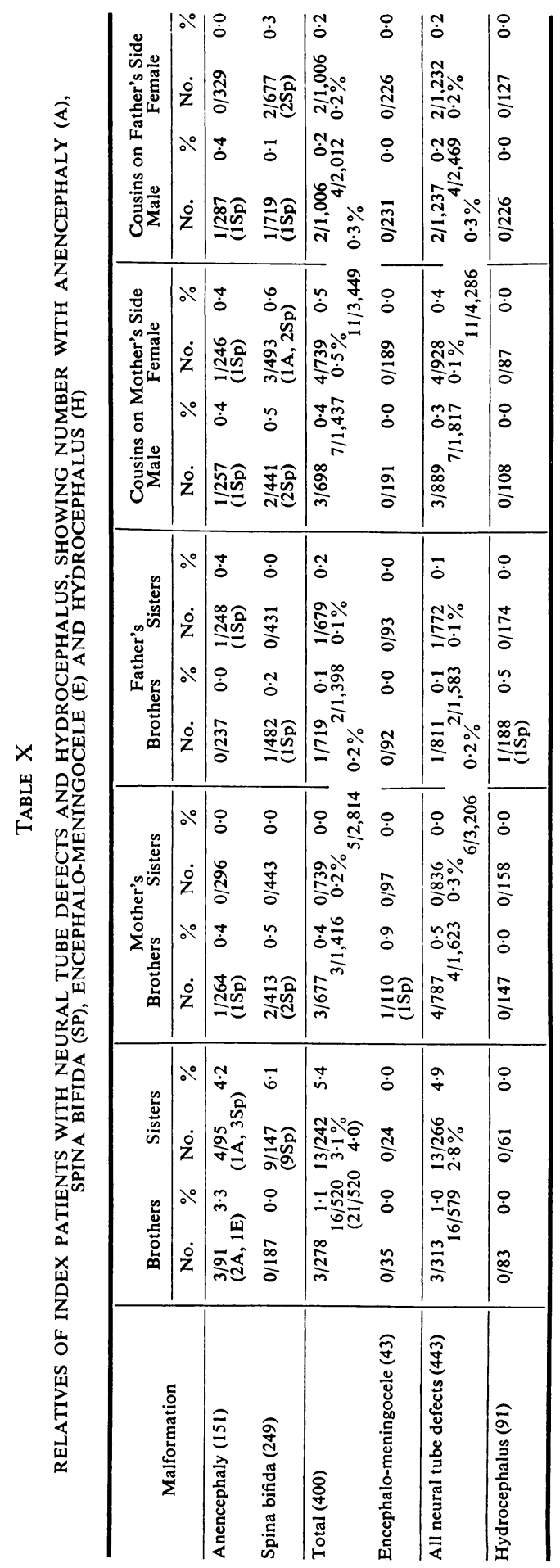


long been known (Malpas, 1937; Hindse-Nielsen, 1938; Polman, 1950; Milham, 1962; Lorber, 1965). The incidence in sibs relative to the incidence in the general population does not vary much between countries, e.g., England (Record and McKeown, 1950a,b; Williamson, 1965), Wales (Carter et al., 1968), the United States (Yen and MacMahon, 1968), and Hungary (see Figure 5).

The frequencies of other congenital malformations in relatives of index patients are shown in Table XI. There is no doubt that in first-, second- and thirddegree relatives of infants born with neural tube defects the incidence of other malformations is not higher than that found in the general population.
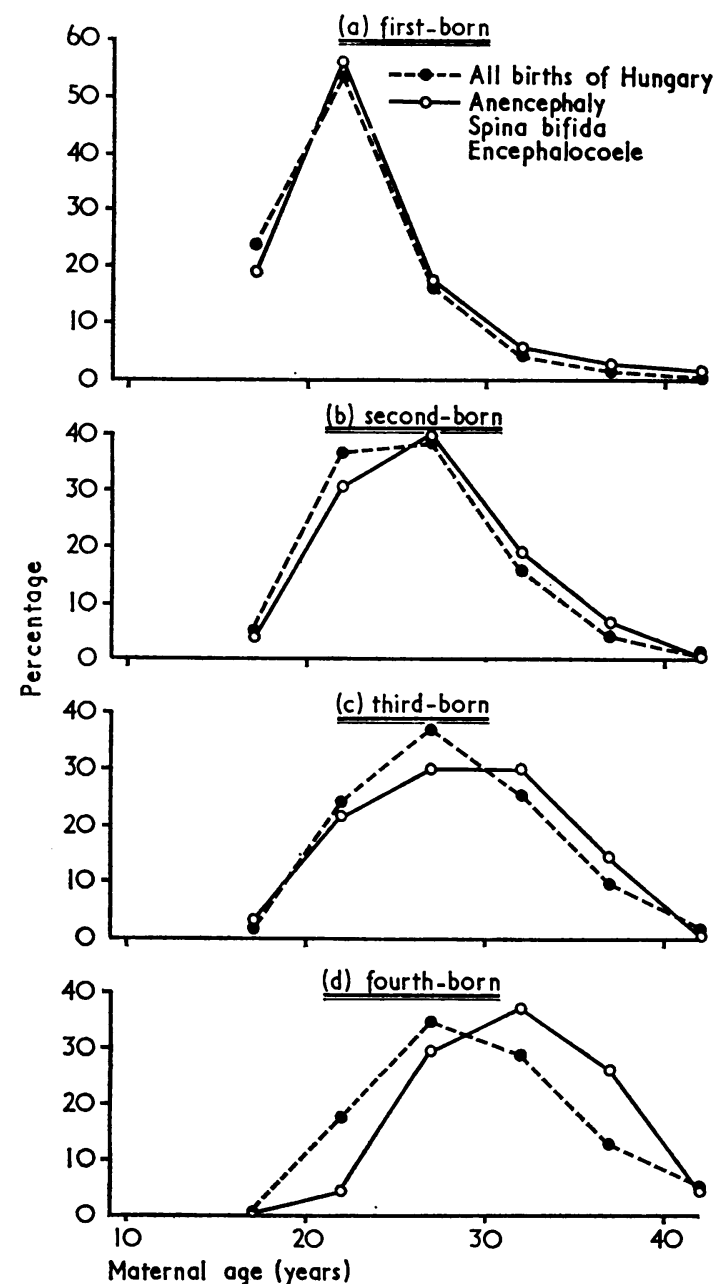

Fig. 4.-Maternal age and the distribution of neural tube defects and all Hungarian births by birth order.
The type and frequency of consanguinity in the family of index patients are summarized in Table XII. In Hungary the proportion of marriages contracted between close blood relatives (first cousins, aunts-nephews, uncles-nieces) was $7 \cdot 13$ per 1,000 in 1900 and 1.48 per 1,000 in 1946 . Since then these details have not been registered, but the frequency of such marriages is probably decreasing. It is difficult to assess the figures given in Table XII against this background but it seems probable that consanguineous marriages are slightly more frequent among the parents of children with neural tube defects and congenital hydrocephalus than in the general population. Similar conclusions were drawn by Böök and Rayner (1950), Record and McKeown (1950a), and Stevenson et al. (1966).

The ABO blood group distribution of mothers and fathers of affected infants did not differ from that of the general population (Table XIII), but the $R h$ blood group distribution in the spina bifida group and in congenital hydrocephalus differed signifi-

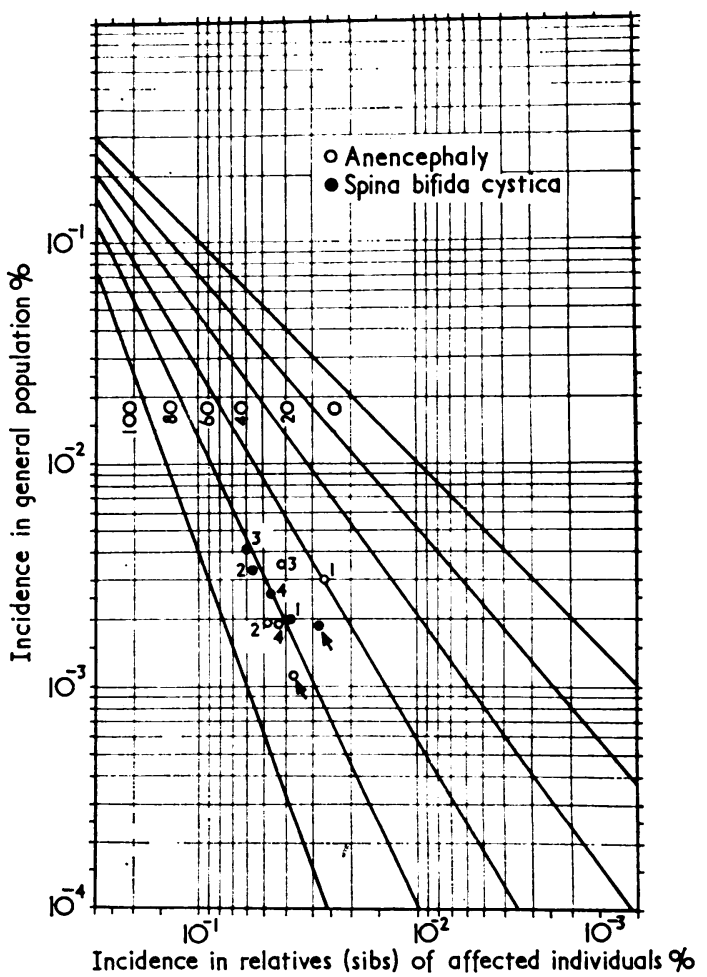

FIG. 5.-Graph for estimating the heritability of anencephaly and spina bifida from the incidences of populations and sibs in (1) Birmingham (Record and McKeown, 1950a,b), (2) Southampton (Williamson, 1965), (3) South Wales (Carter et al., 1968), (4) Rhode Island (Yen and MacMahon, 1968) and $(\uparrow)$ Hungary. 
TABLE XI

OTHER CONGENITAL MALFORMATIONS IN RELATIVES OF INDEX PATIENTS WITH NEURAL TUBE DEFECTS

\begin{tabular}{|c|c|c|c|c|c|c|c|c|c|c|c|c|}
\hline \multirow{3}{*}{ Malformation } & \multirow[b]{3}{*}{$\begin{array}{c}\text { Brothers } \\
\text { (313) }\end{array}$} & \multirow[b]{3}{*}{$\begin{array}{c}\text { Sisters } \\
(266)\end{array}$} & \multirow{2}{*}{\multicolumn{2}{|c|}{ Mother's }} & \multirow{2}{*}{\multicolumn{2}{|c|}{ Father's }} & \multicolumn{4}{|c|}{ Cousins } & \multirow{2}{*}{\multicolumn{2}{|c|}{ Total }} \\
\hline & & & & & & & \multicolumn{2}{|c|}{ Mother's Side } & \multicolumn{2}{|c|}{ Father's Side } & & \\
\hline & & & $\begin{array}{c}\text { Brothers } \\
\text { (787) }\end{array}$ & $\begin{array}{c}\text { Sisters } \\
(836)\end{array}$ & $\begin{array}{c}\text { Brothers } \\
\text { (811) }\end{array}$ & $\begin{array}{c}\text { Sisters } \\
(772)\end{array}$ & $\begin{array}{l}\text { Male } \\
(889)\end{array}$ & $\begin{array}{c}\text { Female } \\
(\mathbf{9 2 8 )}\end{array}$ & $\begin{array}{c}\text { Male } \\
(1,237)\end{array}$ & $\begin{array}{l}\text { Female } \\
(\mathbf{1 , 2 3 2})\end{array}$ & $\begin{array}{l}\text { No. } \\
(8,071)\end{array}$ & $\%$ \\
\hline \multirow{7}{*}{$\begin{array}{l}\text { Hydrocephalus } \\
\text { Mental retardation } \\
\text { Congenital deafness } \\
\text { Hare lip with cleft palate, } \\
\text { or cleft palate } \\
\text { Congenital heart disease } \\
\text { Visceral malformation } \\
\text { (anal atresia, } \\
\text { diaphragmatic hernia) } \\
\text { Congenital dislocation of } \\
\text { hip } \\
\text { Polydactyly, syndactyly } \\
\text { Talipes } \\
\text { Limb deformity } \\
\text { Unidentifiable }\end{array}$} & -1 & $\underline{1}$ & $\begin{array}{l}\overline{3} \\
1\end{array}$ & $\underline{1}$ & 二 & $-\frac{3}{-}$ & $\underline{-}$ & 二 & $\overline{1}$ & $\frac{1}{3}$ & $\begin{array}{r}2 \\
10 \\
5\end{array}$ & $\begin{array}{l}0.2 \\
1.2 \\
0.6\end{array}$ \\
\hline & $\frac{1}{2}$ & $\overline{1}$ & $\overline{2}$ & 1 & $\begin{array}{l}1 \\
1\end{array}$ & $\overline{1}$ & $\begin{array}{l}3 \\
3\end{array}$ & $\begin{array}{l}1 \\
3\end{array}$ & 1 & 1 & $\begin{array}{r}9 \\
14\end{array}$ & $\begin{array}{r}1.1 \\
17 \cdot 3\end{array}$ \\
\hline & - & - & 一 & - & - & - & 2 & 2 & - & - & 4 & 0.5 \\
\hline & 1 & 5 & - & 1 & - & 2 & 3 & 6 & - & 4 & 22 & \\
\hline & - & - & 1 & - & - & 1 & - & 1 & 1 & - & 4 & 0.5 \\
\hline & 一 & - & - & - & - & 1 & 一 & - & -1 & 1 & 2 & $0 \cdot 2$ \\
\hline & 二 & 二 & 二 & 二 & 二 & $\overline{1}$ & 二 & $\overline{1}$ & $\begin{array}{l}1 \\
1\end{array}$ & 1 & $\begin{array}{l}2 \\
3\end{array}$ & $\begin{array}{l}0 \cdot 2 \\
0 \cdot 4\end{array}$ \\
\hline $\begin{array}{l}\text { Total } \\
\text { No. } \\
\text { Per } 1,000\end{array}$ & \multicolumn{2}{|c|}{$\stackrel{5}{15 \cdot 9}^{12}{ }^{26 \cdot 3}{ }^{7}$} & \multicolumn{2}{|c|}{$\begin{array}{ccc}8 \cdot 9 & & 3 \\
& 10 & 3 \cdot 6 \\
(6 \cdot 2) & \end{array}$} & \multicolumn{2}{|c|}{$\begin{array}{cc}2 & \\
2 \cdot 4 & \\
& 11 \\
& (6 \cdot 9)\end{array}$} & \multicolumn{2}{|c|}{$\begin{array}{cr}13 & 14 \\
14 \cdot 6 & 15 \cdot 1 \\
27 & \\
(14 \cdot 9) & \end{array}$} & \multicolumn{2}{|c|}{ 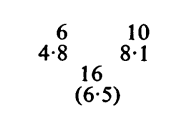 } & $\begin{array}{r}76 \\
9 \cdot 4\end{array}$ & $9 \cdot 4$ \\
\hline $\begin{array}{l}\text { First week's mortality } \\
\%\end{array}$ & $\begin{array}{r}9 \\
2 \cdot 9\end{array}$ & $\begin{array}{r}12 \\
4 \cdot 5\end{array}$ & $\begin{array}{r}24 \\
3 \cdot 1\end{array}$ & $\begin{array}{r}37 \\
4 \cdot 4\end{array}$ & $\begin{array}{r}11 \\
1 \cdot 4\end{array}$ & $\begin{array}{r}8 \\
1 \cdot 0\end{array}$ & $\begin{array}{r}9 \\
1 \cdot 0\end{array}$ & $\begin{array}{l}16 \\
1 \cdot 7\end{array}$ & $\begin{array}{r}5 \\
0 \cdot 4\end{array}$ & $\begin{array}{r}6 \\
0 \cdot 5\end{array}$ & $\begin{array}{r}134 \\
1 \cdot 6\end{array}$ & $16 \cdot 6$ \\
\hline
\end{tabular}

TABLE XII

INSTANCES OF CONSANGUINITY IN THE SERIES

\begin{tabular}{|c|c|c|c|c|c|c|c|}
\hline \multirow{3}{*}{ Malformation } & \multirow{3}{*}{$\begin{array}{l}\text { No. of Index } \\
\text { Patients }\end{array}$} & \multicolumn{4}{|c|}{ Consanguinity } & \multicolumn{2}{|c|}{ Total } \\
\hline & & \multicolumn{2}{|c|}{ Parents } & \multicolumn{2}{|c|}{ Grandparents } & \multirow[b]{2}{*}{ No. } & \multirow[b]{2}{*}{$\%$} \\
\hline & & $\begin{array}{c}\text { 1st } \\
\text { Cousins }\end{array}$ & $\begin{array}{l}\text { 2nd } \\
\text { Cousins }\end{array}$ & $\begin{array}{c}\text { 1st } \\
\text { Cousins }\end{array}$ & $\begin{array}{l}\text { 2nd } \\
\text { Cousins }\end{array}$ & & \\
\hline $\begin{array}{l}\text { Anencephaly } \\
\text { Spina bifida } \\
\text { Encephalo-meningocele }\end{array}$ & $\begin{array}{r}151 \\
249 \\
43\end{array}$ & - & $\begin{array}{r}1 \\
2 \\
-\end{array}$ & $\begin{array}{l}3 \\
2 \\
1\end{array}$ & $\begin{array}{l}1 \\
4 \\
2\end{array}$ & $\begin{array}{l}5 \\
8 \\
3\end{array}$ & $\begin{array}{l}3 \cdot 3 \\
3 \cdot 2 \\
6 \cdot 9\end{array}$ \\
\hline $\begin{array}{l}\text { All neural tube defects } \\
\text { Hydrocephalus }\end{array}$ & $\begin{array}{r}443 \\
91\end{array}$ & $\overline{1}$ & $\begin{array}{l}3 \\
1\end{array}$ & $\begin{array}{l}6 \\
1\end{array}$ & $\begin{array}{l}7 \\
1\end{array}$ & $\begin{array}{r}16 \\
4\end{array}$ & $\begin{array}{l}3 \cdot 6 \\
4 \cdot 4\end{array}$ \\
\hline
\end{tabular}

TABLE XIII

ABO BLOOD GROUP DISTRIBUTION OF MOTHERS OF INDEX CASES AND OF A SAMPLE OF THE HUNGARIAN POPULATION (BASED ON 88,971 HEALTHY DONORS)

\begin{tabular}{|c|c|c|c|c|c|c|c|c|c|c|c|}
\hline Malformation & No. & $\%$ & No. & $\%$ & No. & $\%$ & No. & $\%$ & No. & als & Unknown \\
\hline $\begin{array}{l}\text { Anencephaly } \\
\text { Spina bifida } \\
\text { Encephalo-meningocele }\end{array}$ & $\begin{array}{r}59 \\
61 \\
9\end{array}$ & $\begin{array}{l}43 \cdot 4 \\
33 \cdot 5 \\
37 \cdot 5\end{array}$ & $\begin{array}{r}28 \\
35 \\
8\end{array}$ & $\begin{array}{l}20 \cdot 6 \\
19 \cdot 2 \\
33 \cdot 3\end{array}$ & $\begin{array}{r}12 \\
17 \\
1\end{array}$ & $\begin{array}{l}8 \cdot 8 \\
9 \cdot 3 \\
4 \cdot 2\end{array}$ & $\begin{array}{r}37 \\
69 \\
6\end{array}$ & $\begin{array}{l}27 \cdot 2 \\
37 \cdot 9 \\
25 \cdot 0\end{array}$ & $\begin{array}{r}136 \\
182 \\
24\end{array}$ & $\begin{array}{l}100 \cdot 0 \\
100 \cdot 0 \\
100 \cdot 0\end{array}$ & $\begin{array}{r}224 \\
412 \\
92\end{array}$ \\
\hline $\begin{array}{l}\text { All neural tube defects } \\
\text { Hydrocephalus }\end{array}$ & $\begin{array}{r}129 \\
31\end{array}$ & $\begin{array}{l}37 \cdot 7 \\
41 \cdot 9\end{array}$ & $\begin{array}{r}71 \\
9\end{array}$ & $\begin{array}{l}20 \cdot 8 \\
12 \cdot 2\end{array}$ & $\begin{array}{r}30 \\
8\end{array}$ & $\begin{array}{r}8 \cdot 8 \\
10 \cdot 8\end{array}$ & $\begin{array}{r}112 \\
26\end{array}$ & $\begin{array}{l}32 \cdot 7 \\
35 \cdot 1\end{array}$ & $\begin{array}{r}342 \\
74\end{array}$ & $\begin{array}{l}100 \cdot 0 \\
100 \cdot 0\end{array}$ & $\begin{array}{l}728 \\
171\end{array}$ \\
\hline Total (Malformed Births) & 160 & $38 \cdot 5$ & 80 & $19 \cdot 2$ & 38 & $9 \cdot 1$ & 138 & $33 \cdot 2$ & 416 & $100 \cdot 0$ & 899 \\
\hline Hungary & - & $41 \cdot 6$ & - & $17 \cdot 1$ & - & $10 \cdot 1$ & - & $31 \cdot 2$ & - & $100 \cdot 0$ & - \\
\hline
\end{tabular}


TABLE XIV

PROPORTION OF RHESUS POSITIVE AND NEGATIVE MOTHERS OF INDEX CASES AND OF A SAMPLE OF THE HUNGARIAN POPULATION (BASED ON 88,971 HEALTHY DONORS)

\begin{tabular}{|c|c|c|c|c|c|c|c|c|}
\hline \multirow{2}{*}{$\begin{array}{l}\text { Malformation } \\
\text { Anencephaly } \\
\text { Spina bifida } \\
\text { Encephalo-meningocele }\end{array}$} & \multicolumn{2}{|c|}{$\begin{array}{l}\text { Rh. Positive } \\
\text { No. } \%\end{array}$} & \multicolumn{2}{|c|}{$\begin{array}{l}\text { Rh. Negative } \\
\text { No. } \%\end{array}$} & \multicolumn{2}{|c|}{$\begin{array}{l}\text { Total } \\
\text { No. }\end{array}$} & \multirow{2}{*}{$\begin{array}{c}\begin{array}{c}\text { Deviation from } \\
\text { National Average }\end{array} \\
\chi^{2}=0.194 ; P>0.05 \\
\chi^{2}=8.468 ; P<0.01 \\
\chi^{2}=0.203 ; P>0.05\end{array}$} & \multirow{2}{*}{$\begin{array}{c}\text { Unknown } \\
244 \\
458 \\
102\end{array}$} \\
\hline & $\begin{array}{c}97 \\
102 \\
12\end{array}$ & $\begin{array}{r}83.6 \\
75.0 \\
85.7\end{array}$ & $\begin{array}{r}19 \\
34 \\
2\end{array}$ & $\begin{array}{l}16 \cdot 4 \\
25 \cdot 0 \\
14 \cdot 3\end{array}$ & $\begin{array}{r}116 \\
136 \\
14\end{array}$ & $\begin{array}{l}100 \cdot 0 \\
100.0 \\
100.0\end{array}$ & & \\
\hline $\begin{array}{l}\text { All neural tube defects } \\
\text { Hydrocephalus }\end{array}$ & $\begin{array}{r}211 \\
36\end{array}$ & $\begin{array}{l}79 \cdot 3 \\
73 \cdot 5\end{array}$ & $\begin{array}{l}55 \\
13\end{array}$ & $\begin{array}{l}20 \cdot 7 \\
26 \cdot 5\end{array}$ & $\begin{array}{r}266 \\
49\end{array}$ & $\begin{array}{l}100 \cdot 0 \\
100 \cdot 0\end{array}$ & $\begin{array}{l}\chi^{2}=6.052 ; P<0.05 \\
\chi^{2}=3.92 ; P<0.05\end{array}$ & $\begin{array}{l}804 \\
196 \\
\end{array}$ \\
\hline Total (Malformed Births) & 247 & $78 \cdot 4$ & 68 & $21 \cdot 6$ & 315 & $100 \cdot 0$ & - & 1,000 \\
\hline Hungary & - & $85 \cdot 2$ & - & $14 \cdot 8$ & - & $100 \cdot 0$ & - & \\
\hline
\end{tabular}

cantly from the sample of the general population, the proportion of $\mathrm{Rh}$ negative mothers of these children being unusually high (Table XIV). Because of the small number of cases and because of the lack of direct blood group determination these findings need further investigation.

Coffey and Jessop (1957) observed a significantly higher incidence rate of anencephalics in mothers of blood group O. Wiener (1946) attached importance to $R h$ incompatibility in relation to spina bifida. Later investigations have not confirmed these relationships.

\section{Discussion}

Multifactorial inheritance has been suggested as the most plausible hypothesis in the aetiology of neural tube defects (Carter, 1969). The following observations may be relevant to a consideration of this hypothesis.

1. According to Edwards's formula, if $p$ is the population incidence, the expected incidence in first-, second- and third-degree relatives is $p^{2 / 5}, p^{2 / 3}$ and $p^{4 / 5}$ (Edwards, 1960). In the case of neural tube defects it is difficult to determine the incidence in second- and third-degree relatives, so investigation must be concentrated on sibs. For neural tube defects, $p$ in Budapest is 3 per 1,000 , so that $p^{2 / 5}$ is 97.9 per 1,000 . The incidence in first-degree relatives would therefore be 33 times higher than that in the general population of births. In our series, however, the incidence in sibs was 30.8 per 1,000 , i.e., only 10.3 times higher. The difference may be accounted for in various ways. It is possible that the incidence in sibs has been under-estimated, but a more likely explanation is that if these malformations are genetically determined, expressivity of the genes is less than $100 \%$. Using Falconer's $(1965,1967)$ method Carter (1969) estimated the heritability of spina bifida to be about $60 \%$. In our series heritability was estimated at over $80 \%$ for anencephaly, and about $70 \%$ for spina bifida (see Figure 5 ). However, as
Edwards (cited by Falconer (1967)) has pointed out, Falconer's method assumes a normal distribution of liability in relatives as well as in the general population and his table therefore gives only approximate values. Our values are based on a twodimensional normal distribution, according to Owen's (1956) table, and therefore may be more precise.

2. The relative risk to sibs of cases of multifactorially inherited disease depends considerably on the population incidence. The higher the $p$ value, the smaller, relatively, the risk to members of affected families. Consequently, a higher relative frequency in sibs should be found in Hungary (where the incidence of neural tube defects is about 3 per 1,000 ) than in Britain (where the incidence is $5 \cdot 0$ to $7 \cdot 6$ per 1,000 ). This holds true when the present series is compared with those reported from South Wales (Carter et al., 1968) and from Birmingham (Record and McKeown, 1950a,b) but fails in the comparison with Southampton (Williamson, 1965).

3. The degree of risk to subsequent sibs rises steeply as the number of affected in the sibship increases. In England, where the general risk of anencephaly and spina bifida is about $0.5 \%$, the risk of recurrence in succeeding pregnancies is $5 \%$ after one such malformation and $10 \%$ after two (Carter and Roberts, 1967). Similar proportions have been observed in America-0.4, 4, and 12\% (Yen and MacMahon, 1968). Corresponding figures cannot yet be determined for Hungary, but our series contains one sibship with two anencephalics and one encephalo-meningocoele, and one in which all of the five children had spina bifida (see Appendix). There were also 10 women who had had two affected children. It is noteworthy that the $\mathbf{3 7}$ gestations of these 12 women produced only nine healthy infants.

4. There is evidence that in some malformations (e.g., harelip and/or cleft palate) the risk of recurrence within the family is related to the severity of the malformation in the index case. It is not known 
whether this applies to neural tube defects. In our series the frequency of recurrence after anencephaly with spina bifida was not greater than after anencephaly or spina bifida alone. Spina bifida occurred in a sib of six index patients, four of whom had an associated hydrocephalus; one of these had an occipital meningocoele as well.

5. On the basis of a value for heritability of $60 \%$, it has been estimated that when one monozygotic pair of twins is affected with a neural tube defect, the concordance rate should be slightly less than $20 \%$ (Carter et al., 1968). But, apart from Gittelsohn and Milham's (1962) series, the literature contains few reports of concordance in twins. The series assembled in Table III shows only two in $\mathbf{1 6 6}$ pairs $(1 \cdot 2 \%)$.

6. The slightly higher incidence of consanguineous marriages in the families of the index patients with neural tube defects might support the idea of multifactorial inheritance.

On present evidence one can neither support nor refute Carter's hypothesis that neural tube defects can be ascribed to a polygenic mode of inheritance influenced by variables in the intra-uterine environment. The importance of environmental factors has been repeatedly demonstrated and is supported by the present study which showed seasonal variation in the incidence of spina bifida and a raised incidence of neural tube defects among first-born. The extent to which multifactorial inheritance determines these malformations remains an open question.

\section{SUMmaRY}

In Budapest between 1963 and 1967 the overall incidence of major central nervous system malformations was 3.71 per 1,000 total births. Neural tube defects accounted for 2.95 per 1,000 (anencephaly $1 \cdot 10$, spina bifida $1 \cdot 63$, encephalo-meningocele $0 \cdot 22$ ), and 'congenital' hydrocephalus accounted for 0.76 per 1,000 . These incidence rates exceed the international average.

An epidemiological study comprising 1,315 cases showed a large female preponderance among neural tube defect cases. One fourth of the anencephalics, two-thirds of the hydrocephalics and nine-tenths of the spina bifida and encephalo-meningocele cases were live born. There were 15 twin pairs in each of which only one member was affected. The proportion of anencephalics with birth weight less than $2,500 \mathrm{~g}$. was $81.7 \%$ and an appreciable number weighed less than $1,000 \mathrm{~g}$. The number of spina bifida cases born in March was $50 \%$ greater than the monthly average. The incidence of anencephaly and spina bifida was significantly higher among first-born.

The family study of the sibs of index patients showed an incidence of anencephaly or spina bifida of $3.1 \%$, i.e., $10 \cdot 3$ times the population incidence. The incidence of other congenital malformations among the sibs of index cases was not higher than usual.

These investigations could not have been carried out without the unstinting help of Mogens Hauge (Institute for Human Genetics, Copenhagen) and Gabor Tusnadi (Mathematical Institute of the Hungarian Academy of Sciences) in elaborating and processing the material. We should also like to thank Zoltan Bognar (Budapest Municipal Council, Executive Committee, Department of Public Health) for his kind help in detecting the cases, and Elektra Szamarasz and Eva Bárány for their help in collecting data.

\section{REFERENCES}

Beolchini, P. E., and Bailo, U. (1965). Sull' esistenza di variazioni stagionali delta frequenza dell'anencefalia. Minerva ginec., 17, 928.

BööK, J. A., and RAYNER, S. (1950). A clinical and genetical study of anencephaly. Amer. J. hum. Genet., 2,61 .

Butler, N. R., and Alberman, E. D. (Ed.). (1969). Perinatal Problems. The Second Report of the 1958 British Perinatal Mortality Survey. Livingstone, Edinburgh.

CARTER, C. O. (1965). The inheritance of common congenital malformations. In Progress in Medical Genetics. Edited by Steinberg, A. G., and Bearn, H. G. Vol. IV, p. 59. New York.

(1969). Genetics of common disorders. Brit. med. Bull., 25, 52.

- David, P. A., and Laurence, K. M. (1968). A family study of major central nervous system malformations in South Wales. J. med. Genet., 5, 81 .

and ROBERTs, J. A. F. (1967). The risk of recurrence after two children with central-nervous-system malformations. Lancet, 1, 306.

COFFEY, V. P., and JESSOP, W. J. E. (1957). A study of 137 cases of anencephaly. Brit. J. prev. soc. Med., $11,174$.

Dumoulin, J. G., and Gordon, M. E. (1959). Anencephaly in twins. J. Obstet. Gynaec. Brit. Emp., 66, 964.

EDWARDS, J. H. (1958). Congenital malformations of the central nervous system in Scotland. Brit. J. prev. soc. Med., 12, 115.

(1960). Personal communication, Cited by Carter, C. O. (1965).

FALCONER, D. S. (1965). The inheritance of liability to certain diseases, estimated from the incidence among relatives. Ann. hum. Genet., 29, 51.

(1967). The inheritance of liability to diseases with variable age of onset, with particular reference to diabetes mellitus. Ann. hum. Genet., 31, 1.

Frézal, J., Kelley, J., Guillemot, M. L., and Lamy, M. (1964). Anencephaly in France. Amer. J. hum. Genet., $16,336$.

GitTelsohn, A. M., and Milham, S. (1962). Declining incidence of central nervous system anomalies in New York State. Brit. J. prev. soc. Med., 16, 153. 
Gruber, G. B. (1934). Vorweisungen zur Frage der Entstehung einiger Missbildungen (Anenzephalie. Spina bifida, Arhinenzephalie, Hemizephalie). Verh. dtsch. path. Ges., 27, 303.

GuthKelCH, A. N. (1962). Studies in spina bifida cystica. III. Seasonal variation in the frequency of spina bifida births. Brit. J. prev. soc. Med., 16, 159.

HINDSE-NiElsen, S. (1938). Spina bifida-Prognose; Erblichkeit. Acta chir. scand., 80, 525.

Ingalls, T. H., Pugh, T. F., and MacMahon, B. (1954). Incidence of anencephalus, spina bifida, and hydrocephalus related to birth rank and maternal age. Brit. J. prev. soc. Med., 8, 17.

Laurence, K. M., Carter, C. O., and David, P. A. (1968a). Major central nervous system malformations in South Wales. I. Incidence, local variations and geographical factors. Brit. J. prev. soc. Med., 22, 146.

$\longrightarrow,-$, and $-(1968 \mathrm{~b})$, Major central nervous system malformations in South Wales. II. Pregnancy factors, seasonal variation, and social class effects. Brit. J. prev. soc. Med., 22, 212.

LECK, I., and RECORD, R. G. (1966). Seasonal incidence of anencephalus. Brit. J. prev. soc. Med., 20, 67.

LORBER, J. (1965). The family history of spina bifida cystica. Pediatrics, 35, 589.

McKeown, T., and Record, R. G. (1951). Seasonal incidence of congenital malformations of the central nervous system. Lancet, 1, 192.

MacMahon, B., Pugh, T. F., and Ingalls, T. H. (1953). Anencephalus, spina bifida, and hydrocephalus. Incidence related to sex, race, and season of birth and incidence in siblings. Brit. J. prev. soc. Med., 7, 211.

MALPAS, P. (1937). The incidence of human malformations and the significance of changes in the maternal environment in their causation. J. Obstet. Gynaec. Brit. Emp., 44, 434.

MILHAM, S. (1962). Increased incidence of anencephalus and spina bifida in siblings of affected cases. Science, 138, 593.

Nishimura, H., Takano, K., Tanimura, T., Yasuda, M., and UCHIDA, T. (1966). High incidence of several malformations in the early human embryos as compared with infants. Biol. Neonat. (Basel), 10, 93.

OWEN, D. B. (1956). Tables for computing bivariate normal probabilities. Ann. math. Stat., 27, 1075.

Penrose, L. S. (1946). Familial data on 144 cases of anencephaly, spina bifida and congenital hydrocephaly. Ann. Eugen. (Lond.), 13, 73.
Polman, A. (1950). Anencephaly, spina bifida and hydrocephaly. Genetica, 25, 29.

RECORD, R. G. (1961). Anencephalus in Scotland. Brit. J.prev. soc. Med., 15, 93.

—, and McKeown, T. (1949). Congenital malformations of the central nervous system. I. A survey of 930 cases. Brit. J. soc. Med., 3, 183.

$\longrightarrow$, and (1950a). Congenital malformations of the central nervous system. II. Maternal reproductive history and familial incidence. Brit. J. soc. Med., 4, 26.

, and - (1950b). Congenital malformations of the central nervous system. III. Risk of malformation in sibs of malformed individuals. Brit. J. soc. Med., 4, 217.

- and (1951). Congenital malformations of the central nervous system. Data on 69 pairs of twins. Ann. Eugen. (Lond.), 15, 285.

ScotT, J. M., and Paterson, L. (1966). Monozygous anencephalic triplets-a case report. J. Obstet. Gynaec. Brit. Cwlth, 73, 147.

Slater, B. C. S., Watson, G. I., and McDonald, J. C. (1964). Seasonal variation in congenital abnormalities. Brit. J. prev. soc. Med., 18, 1.

Smithells, R. W., Chinn, E. R., and Franklin, D. (1964). Anencephaly in Liverpool. Develop. Med. Child Neurol., 6, 231.

Stevenson, A. C., Dudgeon, M. Y., and McClure, H. I. (1959). Observations on the results of pregnancies in women resident in Belfast. I. Abortions, hydatidiform moles and ectopic pregnancies. Ann. hum. Genet., 23, 395.

-, Johnston, H. A., Stewart, M. I. P., and Golding, D. R. (1966). Congenital malformations. A report of a study of series of consecutive births in 24 centres. Bull. Wld Hlth Org., 34, Suppl.

TüNTE, W. (1968). Zur Häufigkeit angeborener Missbildungen des Zentralnervensystems und des Verdauungstraktes in der Jahren 1950-1961. Hum. Genet., 6, 29.

WIENER, A. S. (1946). Notes on the pathogenesis of congenital hemolytic disease (erythroblastosis fetalis). Amer. J. clin. Path., 16, 319.

Williamson, E. M. (1965). Incidence and family aggregation of major congenital malformations of central nervous system. J. med. Genet., 2, 161.

Wilson, J. K. (1955). Mono-amniotic multiple pregnancy. J. Obstet. Gynaec. Brit. Emp., 62, 605.

YEN, S., and MACMAHON, B. (1968). Genetics of anencephaly and spina bifida. Lancet, 2, 623. 


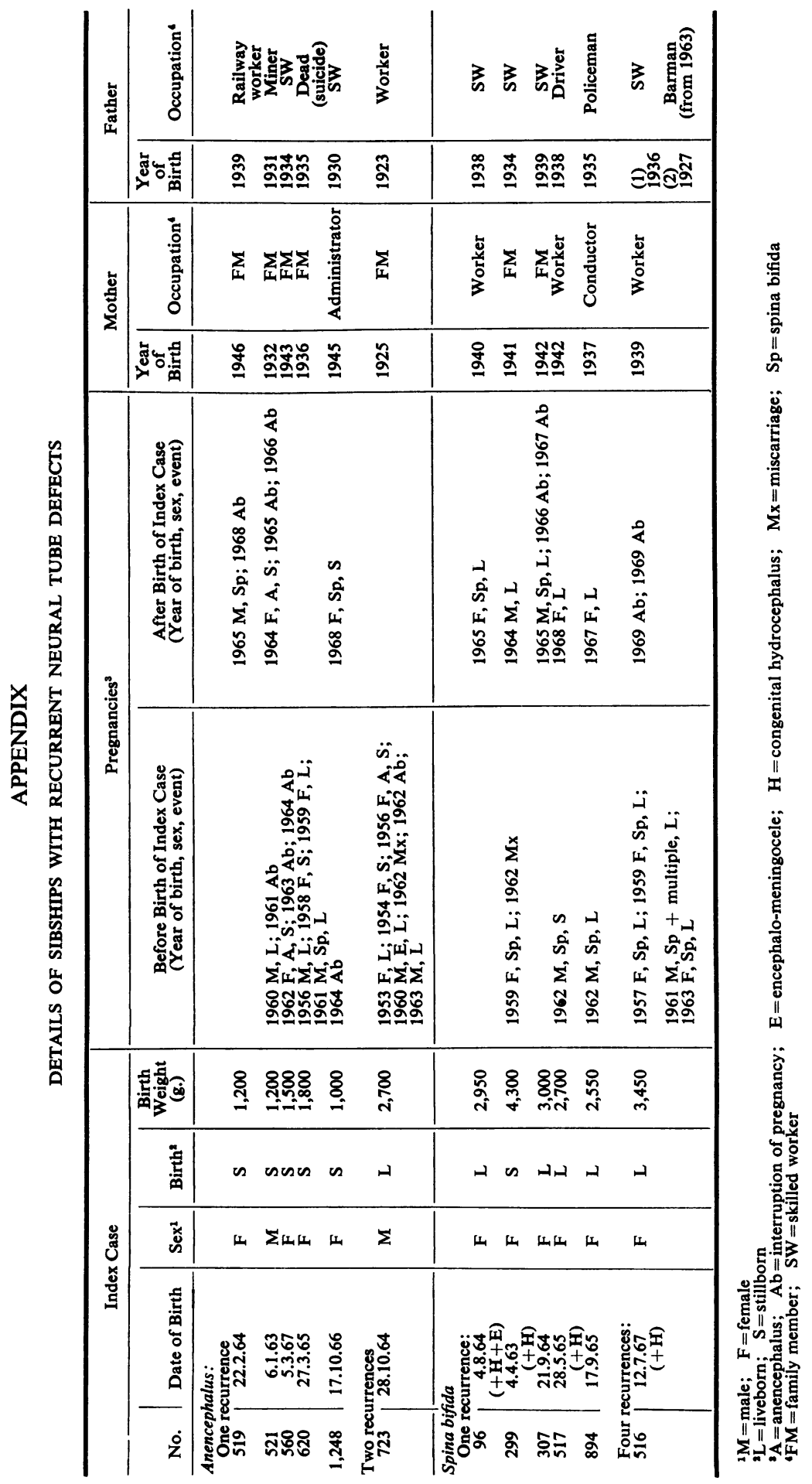

